\title{
THE HALAL FASHION TRENDS FOR HIJABI COMMUNITY: IDEOLOGY AND CONSUMPTION
}

\author{
Nilda Susilawati ${ }^{1}$, Miti Yarmunida ${ }^{2}$, Khairiah Elwardah ${ }^{3}$ \\ Faculty of Islamic Economy and Business IAIN Bengkulu \\ nilda79@iainbengkulu.ac.id ${ }^{1}$, miti yarmunida@iainbengkulu.ac.id ${ }^{2}$, \\ khairiahelwardah@iainbengkulu.ac.id ${ }^{3}$
}

\begin{abstract}
The research is based on a large enough market potential for the development of the halal fashion industry in Indonesia. The hijab fashion trend is a production target that continues to develop with various technologies and innovations, which encourage the consumption of community groups to use hijab fashion to continue to increase.

The study was conducted to determine the purpose of the hijab community in using halal hijab fashion as part of their identity in demonstrating the existence of the hijab group through the ideological and consumption approaches. Qualitative analysis is carried out to determine the ideological emphasis and consumption of the hijab community through open interviews to obtain a clear picture of the social situation. The results show that religious beliefs are the main basis in encouraging the use of hijab and necessity factors.
\end{abstract}

Keywords: Halal fashion, Ideology, Consumption

\section{Introduction}

Referring to Thomson Reuters, the growth of the market share of the Islamic economy is predicted to continue to grow to 3,007 billion USD in 2023. The number of Muslims in the world which reaches 1.8 billion or 24 percent of the global population, and the increasing millennial Muslim population as a generation that participates in influence the prospects and trends of Muslim fashion in the future. Indonesia is the third largest consumer of Muslim clothing in the world, spending 20 billion USD or around IDR 300 trillion. Indonesian Muslim fashion products have great potential as a commodity to integrate international cooperation and make Indonesia the center of the global halal industry. In line with the target set by the government to make Indonesia the center of world Muslim fashion. With a target to market Indonesian Muslim clothing products on a global scale, Bank Indonesia is in synergy with the Indonesian Fashion Chamber (IFC) and the Indonesia Halal Lifestyle Center (IHLC). The similar was conveyed by IFC National Chairman Ali Charisma, if the Indonesian Muslim fashion industry has experienced a significant increase which also offers diversity and unique local content that other countries 
do not have. (W-1), is a big potential for the world's halal fashion market share. According to the Global Islamic Economy Report, Indonesia ranks 3rd in the consumption of Muslim fashion after Turkey and the United Arab Emirates.

Table 1

\begin{tabular}{clc}
\multicolumn{3}{c}{ Consumption Value of Muslim Fashion (billion) } \\
\hline No & \multicolumn{1}{c}{ Country } & Total \\
\hline $\mathbf{1}$ & Turkey & USD 39,3 \\
$\mathbf{2}$ & United Arab Emirates & USD 22,5 \\
$\mathbf{3}$ & Indonesia & USD 18,8 \\
$\mathbf{4}$ & Iran & USD 17,1 \\
$\mathbf{5}$ & Saudi Arabia & USD 16,0 \\
$\mathbf{6}$ & Nigeria & USD 14,4 \\
$\mathbf{7}$ & Egypt & USD 13,7 \\
$\mathbf{8}$ & Russia & USD 13,1 \\
$\mathbf{9}$ & Pakistan & USD 11,4 \\
$\mathbf{1 0}$ & India & USD 10,3 \\
$\mathbf{1 1}$ & Bangladesh & USD 7,0 \\
$\mathbf{1 2}$ & Iraq & USD 6,9 \\
$\mathbf{1 3}$ & USA & USD 6,7 \\
$\mathbf{1 4}$ & Kuwait & USD 4,4 \\
$\mathbf{1 5}$ & German & USD 4,2 \\
\hline & Source: Global Islamic Economy Report, 2014-2015
\end{tabular}

Many efforts to make Indonesia the center of the world's Muslim fashion are intensively carried out by Islamic economic activists, one of which is by holding various events such as the Indonesia International Halal Lifestyle Expo \& Conference (IIHLEC) 2016, Indonesia Sharia Economic Festival (ISEF) 2019. This event is a special attraction. for women to be a reference for Muslim clothing fashions to be used. But still pay attention to the supply chain of Muslim clothing starting from the materials used, the production process, distribution and marketing are carried out with the provisions of Islamic law so that the products produced are halal fashion. The development of halal fashion trends in Indonesia is triggered by the need for halal products in the form of goods and services, the diversity of halal products, a strong legal basis, the increase in halal business actors and the need for halal product exports (Faried, 2019).

Halal has become a lifestyle that covers various aspects of life. The acceptance of halal standards is not only dominated by countries with Muslim populations, but also by countries with Muslim minorities. This acceptance is based on knowledge of sustainability and the impact of Halal products and services on the whole of life. Indonesian Muslim clothing has represented the halal lifestyle in the world (Fithriana and Nopitasari, 2018). Indonesian Muslim clothing is currently in the spotlight and attention for industrial entrepreneurs engaged in Muslim clothing due to has very large prospects. Muslim clothing currently has a large market interest and demand. The sharia-based (halal) industry is 
currently very concerned and in demand by the Indonesian people because the majority of the Indonesian population is Muslim. Halal is no longer only a necessity for Muslims, but has become a global trend that is universal, such as Zoya's products in the form of fashion and cosmetics being one of the pioneers of halal-certified brands (Haro, 2020). Some groups of women who wear hijab also make the hijab trend a group identity which is often known as the bijabi community.

The hijabi community is a group of women who consistently wear the hijab with an attractive appearance, to inspire many women in using the hijab by prioritizing appearances according to Islamic law, but still attractive and fashionable. On various occasions, the hijabi also carried out social actions and education for the community as a form of presentation and social interaction in the community. Some of the hijabi community are also hijab entrepreneurs who also play an active role in developing halal fashion trends, supported by the role of Islamic financial institutions that support the development of the halal fashion business (Martiana, Maesyaroh and Sobar, 2018) as a form of women's economic empowerment.

The bijabi become an influential part in the world of hijab fashion, the way of dressing and wearing the veil represents Islamic values as a symbol of religion that is inherent and blends in to show themselves as modern, classy women and even leads to consumptive behavior. In the end, hijab fashion displayed on social media is not only motivated by religious motives but as an "instrument" for women in the public sphere or a process to find the identity of young women on Instagram (Kavakci and Kraeplin, 2017) and other social media. Consumption culture has now become a trend for teenagers and groups of people (Rohman, 2016). The products attractiveness and promotions carried out by Muslim fashion producers encourage people to buy the products offered constantly. The development of information through social media plays a big role in disseminating information about the development of halal fashion. This triggers people's consumption attitudes with various motivations.

Based on the results of research, the millennial group assumes that fashion consumption and religious beliefs cannot be separated, even making people loyal in using halal products (Teo, Nik and Azman, 2017) and even becoming a fanatical group (Rubawati et al., 2018). Consumption culture has now become a trend for teenagers and groups of people (Rohman, 2016). According to Buadrillard, nowadays consumer society no longer consumes something based on the basic needs of the object of consumption but prefers the symbols attached to the item. In the end, consumption is an inherent image that is carried out continuously because they feel dissatisfied and it is suspected that this behavior can affect a person's lifestyle (Aprillia, no date), even religion also prohibits consumptive behavior because it is a wasteful attitude and is prohibited because wasteful people are brothers of Satan (QS Al-Isra:5). Religion recommends consuming something according to one's needs, not excessive and according to one's abilities. On the other hand, the 
development of halal fashion encourages some people to buy products even though they are not needed.

This paper aims to provide a description of the behavior, attitudes and understanding of halal hijab fashion among the bijabi community with an emphasis on aspects of ideology and consumption as a current social phenomenology.

\section{Review of Related Literature}

\section{Halal Fashion}

Knowledge of fashion is a dominant and significant factor influencing consumers to use products (Teo, Nik and Azman, 2017). Halal fashion must include the dimensions of excitement, sophistication and fairness as part of their brand development strategy (Zainudin, Haji Hasan and Othman, 2019a), and create a competitive advantage for their business (Zainudin, Haji Hasan and Othman, 2019a) because of religious matters such as Halal certification is a marketing approach in order to be able to attract as many customers as possible (Anggia, 2020).

Islamic law has set a reference that a production is categorized as halal if it meets the criteria of halal and thoyyib starting from materials, tools, processes and results. This concept must be implemented thoroughly and consistently in order to avoid production practices that violate Islamic law. (Rusydiana, 2020). Usually halal production is most often associated with food production and processing industries, but nowadays it is often also relevant to various fields such as pharmaceuticals, health products, tourism, cosmetics and hygiene products, logistics, packaging and others (Dubé, Haijuan and Lijun, 2016 ). The halalness of a product can be measured by the fulfillment of the halal indicators that have been set by the MUI as a certification body. The obligation for product certification is carried out to protect consumers from consuming products that are not halal.

The implications of halal product certification in the business climate are increasingly giving consumers confidence in consuming halal products in Indonesia. Because for consumers the existence of halal certification provides protection, guarantees, product halal information and becomes an instrument of business ethics. For business actors, halal certification provides benefits to increase consumer confidence and reach the global halal food market (Warto and Samsuri, 2020). Halal clothing products are clothing that meets the sharia criteria in dressing and becomes one of the halal lifestyles. Halal lifestyle can include other aspects such as beauty, jewelry and luxury goods, automotive, interior, art, and cultural products (Hanzaee and Chitsaz, 2011). To determine the halalness of fashion products, the raw materials used must be halal, the production and storage processes are not mixed with forbidden or unclean materials, and the distribution process must be in accordance with the benefit of the people and the principle of justice (Muflihin, 2019). The stages from upstream to downstream of the production process of an item will 
provide guarantees to consumers that halal fashion products are in accordance with certification standards in Indonesia as regulated by LPOM MUI / BPJPH.

\section{Ideology}

Ideology was first created in France in 1976 by Desstutt De Tracy, then underwent such a shift and is now a complex understanding (Slamet, 2006). Ideology contains principles or rules that apply to a society including socio-political, cultural, economic, and defense and security aspects (Syamsuddin, 2009). Ideology is a person's belief that is abstract and can be influenced by many things such as religion, Pancasila and other thoughts.

The ideological that has influenced by religious or religious aspects is obtained by someone from the religious principles that are believed. Religion is a collection of religious values in a person. This set of values is related to belief in religious teachings both directly and verbally and indirectly or in the heart. This belief is then appreciated in the form of daily actions and behavior. According to Ancok, D. and Suroso, F.N (2011) dimensions of religiosity can be seen from belief, ideology, religious practice, religious experience, knowledge and consequences of religion. Religious ideology adheres to the principles that have been regulated and determined by the creator. A person's belief believes that truth is a principle that must be implemented.

\section{Consumption}

Consumption is an action of someone takes to reduce or spend the use value of an item/service in meeting needs (Soeharto, 2009). The purpose of consumption is as a way to meet the needs of life, reduce the benefits of an item or service and to get satisfaction. Someone who thinks rationally will consider all aspects before buying a product and alternative that gives him the highest utility (Suprapti, 2010). According to Imam al-Ghazali, everyone has a responsibility to fulfill their needs through halal and thoyyib goods, by prioritizing ethics and norms in their acquisition and use (Syaputra, 2017).

Jean Boaudrullard in his book "The Consumer Society (Myths and Structures)" explains that consumption is regulated by primitive mentalist thinking that is driven by belief in the power of one's mind (Baudrillard, 1998). -days, namely the level of dharuri (principal) needs, hajj needs (secondary), and tahsini (tertiary) needs. To fulfill these three needs, it is necessary to pay attention to the priority scale starting from basic needs, secondary and tertiary needs. Hijab is a garment that is required by Islamic law to cover the aurat, although in its application there are differences between the scholars. According to salafi opinion, the theory of consumption of hijab and sharia veil are basic necessities. On the other hand, consumption follows several parameters including class, gender, ethnicity, religion and others (Mahanani, 2017).

A person in consuming the hijab may be influenced by several factors such as knowledge factors, subjective norms, attitudes, behavioral control, and religious 
commitment. However, so that consumption attitudes can be controlled, a strong religious commitment and the role of the community are needed to be in control (Huda, Hulmansyah and Rini, 2018), and provide education to avoid consumptive patterns. Environmental awareness is expected to be able to control negative attitudes and buy halal hijab products in excess.

Other factors that can also influence someone to buy a product are one's economic factors, psychology, anthropology and sociology. On the other hand, this condition can also be used by producers to market products because based on consumer behavior theory, knowing how someone understands a product by exploring resources (Septiana, 2015) is important to increase productivity and product sales.

\section{Research Methodology Type and scope of the research}

This research is a field research with a qualitative descriptive approach. Research on halal fashion trends in the hijabi community is carried out based on factors of knowledge, attitudes, subjective norms, behavioral control, and religious commitment through in-depth observations and interviews with hijabi members in Bengkulu Province. This qualitative descriptive study will explore primary data through structured interviews and secondary data (sourced from literature and documents relevant to this research) to find answers to the problems studied, then described in the form of paragraph descriptions and tables. To support the need for data and information, a literature review related to this research was also carried out.

The data obtained from observations and initial interviews were then confirmed to 24 participants from 4 hijab communities, namely DANL Fam, Kulwaf (Muslimah Association), Muslimah Perindu Jannah Bengkulu Province, Seinaa Lova Bengkulu in Bengkulu Province. Participants were asked to answer questions through the interview guide as an effort to confirm the data.

The research instrument was carried out directly by the researcher based on the results of the information and data obtained from the participants. In the process of collecting data, researchers used closed interview guidelines, this was to facilitate the interview process in order to obtain the right data and make it easier to classify the information obtained.

This research was conducted from September to November 2019, informants who are members of the hijab community who provide information through interview guidelines that have been provided, both face-to-face and online, this is to facilitate the interview process due to the COVID-19 pandemic, limiting the public to be able to meet directly with the informant during the interview process. Then the researcher did probing as an effort to explore the answers that have been given by the informants. Probing was 
carried out by direct interviews with several informants, either through the internet or through face-to-face meetings.

The data from the interviews were classified thematically to emphasize social phenomena in society through data classification on the basis of themes and considering the aspects covered by the scope of the research. The data were analyzed through three stages, namely data restatement, data description, and data interpretation. The restatement was carried out based on data and information from interviews with participants. The description of the data is carried out to show the patterns and trends of the data about the trend of halal hijab from the hijab community and the next stage is the analysis which is the basis for drawing conclusions (inference).

\section{Result and Discussion}

The research was conducted on 26 respondents who are members of the hijab community in the Bengkulu Province, consisting of 4 hijab groups, namely DANL Fam, Kulwaf (Muslimah Association), Muslimah Perindu Jannah Bengkulu Province, SeinaaLova Bengkulu. The members consist of professional backgrounds such as civil servants, entrepreneurs, housewives and the majority are students with age limits ranging from 20 to 60 years old. In its activities, the hijab community actively campaigns for the sharia hijab, conducts gatherings between members by filling in recitation activities, education, discussions in the fields of health, psychology and current topics that are currently being discussed and social activities in the form of providing assistance or compensation for the underprivileged, orphanages, natural disasters, Friday blessings and others.

This study found that the motivation of hijab members to join the hijab community was because they wanted to expand the association of fellow Muslim women, broaden their religious horizons, because some hijabi communities also conducted studies in the field of religion through regular meetings held every week or month, encouragement from friends who has previously joined a community that provides information and input on the importance of joining the hijab community and as a means of worship to spread religious symbols through the use of religious symbols by using the hijab, because the clothes used show one's identity and attract others to want to wear the hijab as regulated in religion about the obligation of every Muslim woman who is mature to cover her aurat.

Another finding reveals that the ideology believed by hijabi in using hijab halal fashion is influenced by religious beliefs that using a halal hijab is a religious obligation for every Muslim. As a Muslim, you are only allowed to use things that are halal and thoyyib, and you are not allowed to use products that are haram. They understand about this through information media and social media which provides a lot of information about halal and haram products in the form of narratives, pictures and videos of religious lectures, as well as religious knowledge received through formal education levels such as strengthening Islamic Religious Education subjects in schools or other religious education institutions such as madrasas and Islamic boarding schools which teach religious rules regarding the 
provisions of the hijab, aurat, clothing and hijab models, the use of materials and how to obtain halal fashion hijabs and things that are forbidden according to religious rules.

This study also found that knowledge about halal fashion according to the hijabi community that a halal-friendly fashion product does not have to go through the stages of halal certification by BPOM MUI / BPJPH. According to them, the hijab fashion trend has indicated that the product is halal even though it is not certain that it is halal, starting from the production process to marketing it must be in accordance with Islamic law. The names of hijab fashion brands that use Arabic terms such as Rabbani, Elzatta, Zoya and designers who are quite famous for their hijab fashion show that the product has been produced in a halal manner. However, they are not completely sure if the materials used are halal materials, and may also be mixed with other prohibited materials. This is an obligation for producers to use and produce fashion in a halal manner and convince consumers that the materials used in fashion production are made from halal and halal. produced according to Islamic law. This requires more in-depth research to prove the doubts of the hijabi community.

It is a necessity for every consumer to seek information related to halal-friendly product. Information about halal-friendly product is part of consumer protection. Even religion through the hadith of the Prophet narrated by Thabrani which means "Seeking halal is an obligation for every Muslim" (Adinugraha and Sartika, 2019). Producers must prepare information related to halal-friendly product so that the public can find out in detail the ingredients contained in the products consumed. If a product already has a halal certificate, then its halal-friendly can be believed through the MUI fatwa and is indicated by the halal logo on the product packaging. This can make it easier for consumers to find information about the halal products.

This finding also reveals that the attitude of the hijabi community towards halal fashion by seeking information about halal-friendly product is a priority before buying a product and when faced with a halal fashion product brand through the LPOM MUI/BPJPH certification, it will prioritize the product to be purchased, when compared to others fashion products who have not been certified halal. The consumption of halal hijab fashion according to the average hijabi group is also influenced by hijab trends that continue to grow and are up to date, with fashion models that are dancing, contemporary and affordable prices that can be used by all people, making old fashion considered outdated and does not follow the model, even though the hijab has not been fully used. And with the professional background of members of the heterogeneous hijabi community and are career women and are active in various fields and organizations, they also require them to buy halal fashion as a necessity to appear more attractive as part of supporting work and activities. According to Hasan (Hassan and Harun, 2016) that women who are fashion conscious with their unique fashion have a higher tendency than women who do not understand fashion in terms of fashion consumption. Because different hijab clothing 
will show their individuality and tend to be a fashion leader compared to fashion followers (Hassan and Harun, 2016).

Some brands also carry out marketing strategies through giving discounts and gifts for consumers, but that does not attract the hijabi group to buy products, they are more interested in the fashion styles used by the models, because they can directly know whether the product is suitable or not. with one's body posture. Buying halal fashion products out of necessity and not influenced by appearance, prestige, and social status, although there are those who agree but only minority opinions. Consideration of the need for halal fashion takes precedence over just beautifying the appearance with new clothes. This condition is a challenge for manufacturers to be unique in the products they offer, to differentiate them from other products as a competitive advantage in the business world (Zainudin, Haji Hasan, and Othman 2019). In addition, halal certification and halal awareness also influence consumer decisions to choose products (Septiani and Ridlwan, 2020). Marketing strategies must be pursued to attract consumers to buy products.

This study provides a great opportunity for halal fashion producers and the government to develop halal through increasing training, both academically and nonacademically and supporting halal certification regulations, controlling certification fee standards for SMEs, medium and large industries and socializing the halal certification process to the public (Septiani and Ridlwan, 2020). By finding strategies that can encourage halal fashion in Indonesia and synergizing with scholars, designers, halal communities, academics and ministries such as the Ministry of Trade, Ministry of Religion and others to conduct education and socialization about the importance of halal certification for fashion products (Devi and Nawawi, 2018), knowledge about halal literacy and factors related to purchasing halal products will have an influence on halal lifestyle (Sardiana, 2020). The assessment of the halal certification system worldwide reached $12 \%$ showing positive sentiment in 2016, 12\% showing negative sentiment in 2018 and 76\% showing neutral sentiment in 2019. Therefore, stakeholders must take advantage of the momentum of the revival of halal certification throughout the world. world to be a solution for socioeconomic problems and the community will also receive the benefits (Rusydiana, 2020), as the world's Muslim majority country.

\section{Conclusion}

Halal fashion trends are part of economic development, people make halal fashion their self by consistently using the hijab which continues to grow along with the development of world fashion. This encourages the hijabi community to use the hijab against the background of the influence of ideology and consumption attitudes. The majority of members of the hijabi community make religious beliefs the main basis that influences ideology in encouraging the use of halal fashion and factors of need, fashion model and income are quite dominant factors in encouraging consumption of halal fashion, in addition to other factors. 
The government and other related institutions are important factors in supporting the increase in halal certification for fashion products. With the increase in the number of halal certifications for fashion products, it will provide a sense of security and comfort for halal consumers to use halal fashion products. And this can also provide benefits for producers as one of the product attractions. For further researchers, it is recommended to conduct a more in-depth study on the supply and channel aspects of the process of making halal fashion, from upstream to downstream through the implementation of a halal assurance system. Then develop research with a larger community and a wider scope as a scientific development in the field of halal fashion.

\section{Bibliography}

Adinugraha, H. H. and Sartika, M. (2019) 'Halal Lifestyle Di Indonesia', An-Nisbab: Jurnal Ekonomi Syariah, 5(2), pp. 57-81. doi: 10.21274/an.2019.5.2.layout.

Ancok, D. dan Suroso, F. N. (2011) Psikologi Islam: Solusi Islam dalam Problem-problem Psikologi.

Yogyakarta: Pustaka Pelajar.

Anggia, F. (2020) 'Representasi Media Sosial atas Hijabista : Pembentukan Citra Perempuan

Muslim dari Perspektif Konsumsi Info Artikel Keyword Kata Kunci Abstrak', Jurnal Hawa, 2(1), pp. 64-74.

Aprillia, R. (no date) 'Konsumsi dalam pandangan jean baudrillard dan al-ghazali', Ekonomi Dan Keuangan Syariah.

Baudrillard, J. (1998) The Consumer Society, Myths and Structures. London: SAGE Publications, Ltd.

Devi, A. and Nawawi, K. M. (2018) 'Halal Certification Implementation Strategies for Fashion Product', in. SCITEPRESS, pp. 645-649. doi: 10.5220/0007087306450649.

Dubé, F. N., Haijuan, Y. and Lijun, H. (2016) 'Halal certification system as a key determinant of firm internationalisation in the Philippines and Malaysia', Asian Academy of Management Journal, 21(1), pp. 73-88.

Faried, A. I. (2019) 'Implementasi Model Pengembangan Industri Halal Fashion Di Indonesia', Jurnal kajian Ekonomi dan Kebijakan Publik, 4(2), pp. 9-19.

Fithriana, A. and Nopitasari, W. (2018) 'Modest Fashion: Diplomatic Creativity in Supporting Halal Tourism', IJECA (International Journal of Education and Curriculum Application), p. 28. doi: 10.31764/ijeca.v0i0.1974.

Hanzaee, K. H. and Chitsaz, S. (2011) 'A review of influencing factors and constructs on the Iranian women' s Islamic fashion market', Interdisciplinary Journal of Research in Business, 1(April), pp. 94-100.

Haro, A. (2020) 'Are Zoya Muslim Fashion Products as Halal Lifestyle in Consumer Purchase Decision?', Advances in Economics, Business and Management Research, volume 144 23rd Asian Forum of Business Education(AFBE 2019), (June). doi: 10.2991/aebmr.k.200606.033.

Hassan, S. H. and Harun, H. (2016) 'Factors influencing fashion consciousness in hijab 
fashion consumption among hijabistas', Journal of Islamic Marketing, 7(4), pp. 476-494. doi: 10.1108/JIMA-10-2014-0064.

Huda, N., Hulmansyah, H. and Rini, N. (2018) 'Faktor Yang Mempengaruhi Perilaku Konsumsi Produk Halal Pada Kalangan Mahasiswa Muslim', EKUITAS Jurnal Ekonomi dan Keuangan), 2(2), pp. 247-270. doi: 10.24034/j25485024.y2018.v2.i2.3944.

Kavakci, E. and Kraeplin, C. R. (2017) 'Religious beings in fashionable bodies: the online identity construction of hijabi social media personalities', Media, Culture and Society, 39(6), pp. 850-868. doi: 10.1177/0163443716679031.

Mahanani, P. A. R. (2017) 'Perempuan Salafi Memaknai Jilbab: Antara Alternatif dan Oposisional', Jurnal Sosial Politik, 2(1), p. 123. doi: 10.22219/sospol.v2i1.4760.

Martiana, A., Maesyaroh and Sobar (2018) 'Motivation and obstacles faced by women halal fashion entrepreneurs and role of the business on women's economic empowermentin Yogyakarta Indonesia', Humanities and Social Sciences Reviews, 6(2), pp. 106-110. doi: 10.18510/hssr.2018.6213.

Muflihin, M. D. (2019) 'Indikator Halal dalam Industri Halal Fashion', Jurnal Saujana, 01, pp. 53-69. Available at: http://ejournal.steikassi.ac.id/index.php/111/article/view/24.

Rohman, A. (2016) 'Budaya Konsumerisme dan Teori Kebocoran di Kalangan Mahasiswa', KARSA: Jurnal Sosial dan Budaya Keislaman, 24(2), p. 237. doi: 10.19105/karsa.v24i2.894.

Rubawati, E. et al. (2018) 'Halal Women Fashion: Beauty Reflect Blessing', IOP Conference Series: Earth and Environmental Science, 175(1). doi: 10.1088/1755-1315/175/1/012197.

Rusydiana, A. S. and L. M. (2020) 'Analisis Sentimen terkait Sertifikasi Halal', Journal of Economics and Business Aseanomics, 5(110), pp. 69-85.

Sardiana, A. (2020) 'Halal Literacy and Halal Product Purchase Dimension: A Preliminary Study', Insight Journal, (March). doi: 10.13140/RG.2.2.31540.81284.

Septiana, A. (2015) 'Analisis Perilaku Konsumsi Dalam Islam', Dinar, 1(1), pp. 1-17. Available at: https://journal.trunojoyo.ac.id/dinar/article/download/2688/2162.

Septiani, D. and Ridlwan, A. A. (2020) 'The Effects of Halal Certification and Halal Awareness on Purchase Intention of Halal Food Products in Indonesia', Indonesian Journal of Halal Research, 2(2), pp. 55-60. doi: 10.15575/ijhar.v2i2.6657.

Slamet, S. (2006) Filsafat dan Idiologi Pancasila. Yogyakarta: CV. Andi Offset.

Soeharto (2009) Teori Ekonomi Mikro, Beaya Produksi. Yogyakarta: Andi.

Suprapti, N. W. . (2010) Perilaku Konsumen: Pemahaman Dasar dan Aplikasinya dalam Strategi Pemasaran. Denpasar-Bali: Udayana Universiti Press.

Syamsuddin, dkk (2009) Pendidikan Pancasila. Yogyakarta: Total Media.

Syaputra, E. (2017) 'Perilaku Konsumsi Masyarakat Modern Perspektif Islam: Telaah Pemikiran Imam Al-Ghazali dalam Ihya' Ulumuddin', FALAH: Jurnal Ekonomi Syariah, 2(2), p. 144. doi: 10.22219/jes.v2i2.5102. 
Teo, B. C. C., Nik, N. S. and Azman, N. F. (2017) 'Making sense of fashion involvement among Malaysian Gen Y and its implications', Journal of Emerging Economies and Islamic Research, 5(4), p. 10. doi: 10.24191/jeeir.v5i4.6236.

Warto, W. and Samsuri, S. (2020) 'Sertifikasi Halal dan Implikasinya Bagi Bisnis Produk Halal di Indonesia', Al Maal: Journal of Islamic Economics and Banking, 2(1), p. 98. doi: 10.31000/almaal.v2i1.2803.

Zainudin, M. I., Haji Hasan, F. and Othman, A. K. (2019a) 'Halal brand personality and brand loyalty among millennial modest fashion consumers in Malaysia', Journal of Islamic Marketing. doi: 10.1108/JIMA-10-2018-0187.

Zainudin, M. I., Haji Hasan, F. and Othman, A. K. (2019b) 'Halal brand personality and brand loyalty among millennial modest fashion consumers in Malaysia', Journal of Islamic Marketing, (August). doi: 10.1108/JIMA-10-2018-0187. 